\title{
Neuroendocrine tumors: a multidisciplinary approach for a complex disease
}

\author{
Rossana Berardi \\ Medical Oncology Unit, Università Politecnica delle Marche, Azienda Ospedaliero-Universitaria Ospedali Riuniti Umberto I, GM Lancisi, \\ G Salesi di Ancona, Via Conca 71, 60126 Ancona, Italy. \\ Correspondence to: Dr. Rossana Berardi, Medical Oncology Unit, Università Politecnica delle Marche, Azienda Ospedaliero-Universitaria \\ Ospedali Riuniti Umberto I, GM Lancisi, G Salesi di Ancona, Via Conca 71, 60126 Ancona, Italy. E-mail: r.berardi@univpm.it
}

Neuroendocrine neoplasms include a heterogeneous group of neoplasms, representing a spectrum of rare neoplasms arising in different organism sites with different malignant potential and behavior. They typically occur in gastrointestinal and bronchopulmonary tracts.

The incidence and prevalence of these neoplasms showed a significant increase in the last four decades leading to a rising interest in these tumours with remarkable progresses in their both treatment and management. Nevertheless, they are still considered rare diseases with a global clinical incidence of 3.65 cases $/ 100,000$ per year according to the National Cancer Institute SEER (Surveillance Epidemiology and End Results) registry. ${ }^{[1]}$

Surgery still remains the primary treatment approach mainly depending on tumour size, stage and patients performance status. However in loco-regional unresectable and/or metastatic disease, curative surgery is generally not possible, therefore medical therapy is usually primarily considered. Several treatment options are available and to date the management of neuroendocrine tumors within clinical practice is based on a multimodal therapeutic strategy including surgery and other loco-regional therapies, somatostatin analogs (SSAs), peptide receptor radionuclide therapy (PRRT), cytotoxic agents, biological agents (including angiogenesis inhibitors such as sunitinib and inhibitors of mammalian target of rapamycin as everolimus) with a multidisciplinary approach. ${ }^{[2]}$

SSAs, including octreotide and lanreotide, represent effective options in the presence of carcinoid syndrome, but they also have an antiproliferative effect in secreting and nonsecreting neuroendocrine tumors. ${ }^{[3,4]}$

PRRT is an emerging treatment modality for advanced neuroendocrine tumors. It is performed in the treatment

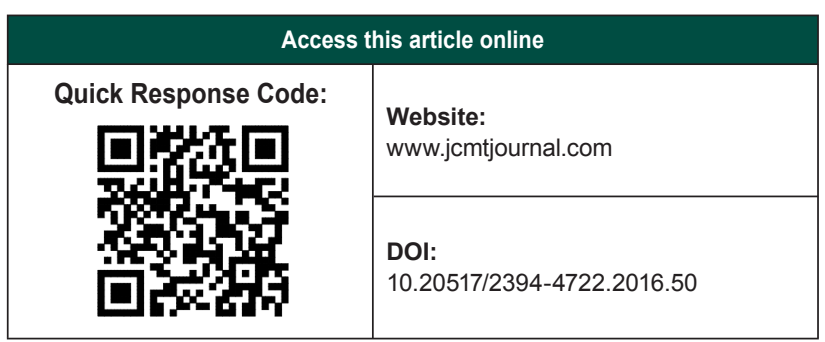

of neuroendocrine tumors, where somatostatin analogues (DOTATOC, DOTATATE) are radiolabeled with ${ }^{177} \mathrm{Lu},{ }^{90} \mathrm{Y}$, or ${ }^{111}$ In for pre-therapeutic and therapeutic purposes. ${ }^{[5]}$

There are many cumulative evidences about the effectiveness and tolerability of this therapeutic approach, especially in gastro-entero-pancreatic neuroendocrine tumors.

Neuroendocrine neoplasms therapy also includes cytotoxic agents, expecially in symptomatic patients, in progressive disease, in case of moderate or poor differentiation and more aggressive features. Chemotherapy schedules used in this setting include alkylating agents (streptozotocin, dacarbazine, and temozolomide), antimetabolites (5-fluorouracil, capecitabine), etoposide and platinum derivatives (including cisplatin and oxaliplatin). ${ }^{[6]}$

The availability of new targeted agents, such as everolimus and sunitinib, which are effective in advanced and metastatic pancreatic neuroendocrine tumors, has provided new treatment opportunities.

Despite comprehensive and interesting medical progress, the current available therapeutic options are still inadequate for gastrointestinal and lung neuroendocrine tumors, mainly due to the lack of in-depth knowledge of molecular mechanisms and predictive factors.

Prognostic evaluation is mainly based on their morphologic features and proliferation index, according to $\mathrm{WHO}$ classification. ${ }^{[7]}$

Due to the usually long life-expectancy of these patients, many different lines of therapy are performed according to

This is an open access article distributed under the terms of the Creative Commons Attribution-NonCommercial-ShareAlike 3.0 License, which allows others to remix, tweak, and build upon the work non-commercially, as long as the author is credited and the new creations are licensed under the identical terms.

For reprints contact: service@oaepublish.com

How to cite this article: Berardi R. Neuroendocrine tumors: multidisciplinary approach for a complex disease. J Cancer Metasta Treat 2016;2:277-8.

Received: 07-08-2016; Accepted: 08-08-2016. 
difference status of the disease as well as on timing. Thus, despite the sequencing of different therapies represents a true challenge in real life, a standard therapeutic sequence is still lacking and it is a matter of debate.

Therefore novel strategies are needed, especially for refractory and/or recurrent neuroendocrine neoplasms that present a poor prognosis. Personalized approaches are currently being developed and molecular targets are emerging.

Several driver pathways have been investigated and they may represent important factors in the carcinogenesis process and, therefore, potential targets for new anticancer therapies.

In particular, activating mutations have been identified several genes, including those of the epidermal growth factor receptor, platelet-derived growth factor receptor, vascular endothelial growth factor, basic-fibroblastic growth factor, transforming growth factor, insulin-like growth factor-1, and their receptors, stem cell factor receptor. New drugs (including immunotherapy) and several combination regimens with new biological agents are being developed and studied in recently conducted and ongoing trials.

Further investigations could increase our knowledge about molecular mechanisms responsible for the neuroendocrine neoplasms heterogeneity, about tumor interactions with adjacent healthy tissue and as regard its variegated response to treatments, to guarantee the development of new promising therapies.

This special issue on neuroendocrine neoplasms aims to summarize the present knowledge about the treatment of these tumors highlighting available evidences as well as new biological perspectives on biological and targeted therapies, also including case reports.

\section{Financial support and sponsorship}

Nil.

\section{Conflicts of interest}

There are no conflicts of interest.

\section{REFERENCES}

1. Yao JC, Hassan M, Phan A, Dagohoy C, Leary C, Mares JE, Abdalla EK, Fleming JB, Vauthey JN, Rashid A, Evans DB. One hundred years after "carcinoid": epidemiology of and prognostic factors for neuroendocrine tumors in 35,825 cases in the United States. J Clin Oncol 2008;26:3063-72.

2. Berardi R, Rinaldi S, Torniai M, Morgese F, Partelli S, Caramanti M, Onofri A, Polenta V, Pagliaretta S, Falconi M, Cascinu S. Gastrointestinal neuroendocrine tumors: Searching the optimal treatment strategy -- A literature review. Crit Rev Oncol Hematol 2016;98:264-74.

3. Rinke A, Müller HH, Schade-Brittinger C, Klose KJ, Barth P, Wied M, Mayer C, Aminossadati B, Pape UF, Bläker M, Harder J, Arnold C, Gress T, Arnold R; PROMID Study Group. Placebocontrolled, double-blind, prospective, randomized study on the effect of octreotide LAR in the control of tumor growth in patients with metastatic neuroendocrine midgut tumors: a report from the PROMID Study Group. J Clin Oncol 2009;27:4656-63.

4. Caplin ME, Pavel M, Ćwikła JB, Phan AT, Raderer M, Sedláčková E, Cadiot G, Wolin EM, Capdevila J, Wall L, Rindi G, Langley A, Martinez S, Blumberg J, Ruszniewski P; CLARINET Investigators. Lanreotide in metastatic enteropancreatic neuroendocrine tumours. N Engl J Med 2014;371:224-33.

5. Hardiansyah D, Maass C, Attarwala AA, Müller B, Kletting P, Mottaghy FM, Glatting G. The role of patient-based treatment planning in peptide receptor radionuclide therapy. Eur J Nucl Med Mol Imaging 2016;43:871-80.

6. Vilar E, Salazar R, Perez-Garcia J, Cortes J, Oberg K, Tabernero J. Chemotherapy and role of the proliferation marker Ki-67 in digestive neuroendocrine tumours. Endocr Relat Cancer 2007;14:221-32.

7. Rindi G, Arnold R, Bosman FT, Capella C, Klimstra DS, Kloppel G, Komminoth P, Solcia E. Nomenclature and classification of neuroendocrine neoplasms of the digestive system. In: WHO Classification of Tumours of the Digestive System, 4th ed, Bosman TF, Carneiro F, Hruban RH, Theise ND (Eds). Lyon: IARC Press; 2010. p.13-4. 